\title{
Non-biological complex drugs (NBCDs) and their follow-on versions: time for an editorial section
}

\author{
Jon SB de Vlieger, PhD; Professor Stefan Mühlebach, PhD; Vinod P Shah, \\ PhD; Scott E McNeil, PhD; Professor Gerrit Borchard, PharmD, PhD; Vera \\ Weinstein, PhD; Beat Flühmann, PhD; Sesha Neervannan, PhD; Professor \\ Daan JA Crommelin, PhD
}

\section{This paper discusses the group of non-biological com- plex drug (NBCD) products and presents the reasons why NBCDs should be assigned a special position in our arsenal of medicines as well as why from now on a special section will be devoted to report on these NBCD products in the GaBI Journal.}

Keywords: Glatiramoids, iron-carbohydrate complexes, liposomes, nanomedicines, Non-Biological Complex Drug (NBCD) products, therapeutic equivalence

\begin{abstract}
Introduction
The concept of non-biological complex drug (NBCD) products has been presented and discussed on several occasions in the GaBI Journal [1-4]. The growing interest in this topic in academic, industrial and regulatory circles led to the establishment of an Editorial Section on Non-Biological Complex Drugs in both the GaBI Journal and GaBI Online starting in the third quarter of 2015.
\end{abstract}

In 2011, the first publication on NBCDs appeared [5] as a result of a workshop held in Leiden, The Netherlands, in 2009. For the first time this class of drug products was identified and recognized. These products are more complex than small, low molecular drugs and as complex or even more complex than biologicals; sharing many of the characteristics of the latter category but not being derived from living sources. As a consequence, the authors argued that for the equivalence testing of NBCD follow-on products a regulatory pathway should be developed that was similar to the pathways developed by the European Medicines Agency (EMA) and later the US Food and Drug Administration (FDA) for approving biosimilars. This proposal was backed up by evidence provided by a (still growing) number of published studies on NBCD follow-on versions that were authorized using a 'standard' but inadequate generic assessment protocol.

A working group hosted by the Dutch Top Institute (TI) Pharma in Leiden was set up to raise awareness of the challenges NBCD products present worldwide, to stimulate the publication of scientific reports and discussions and to provide a rigorous, sciencebased, regulatory policy for NBCD products [6]. These efforts led to a number of publications and a book exclusively dedicated to the NBCD concept and its regulation. These publications provide a definition for NBCD products, discuss different classes of NBCDs, propose an overarching regulatory philosophy for evaluating NBCD follow-on versions and, finally, outline what issues are still unresolved [7-9].

This paper to the GaBI Journal further explains:

- Definition: how NBCD products are defined
- Present product 'families' and beyond: which NBCD product families are identified today and how this group may expand in the coming years

- The regulatory landscape: which regulatory frameworks are in place through EMA and FDA

- Performance of NBCD products and follow-on versions: evidence in the public domain, i.e. what information is accessible in the public domain regarding the performance of NBCD products and their follow-on versions, including some reflections on the nanoparticulate nature of many NBCDs

- The future: Quo Vadis?

\section{Definition}

A definition of NBCD products that was published earlier by the NBCD working group reads: 'A Non-Biological Complex Drug is a medicinal product, not being a biological medicine, where the active substance is not a homo-molecular structure, but consists of different (closely related and often nanoparticulate) structures that can't be isolated and fully quantitated, characterized and/or described by stateof-the-art (physico)chemical analytical means and where the clinical meaning of the observed differences is not known. The composition, quality and in vivo performance of NBCDs are highly dependent on manufacturing processes of both the active ingredient as well as in most cases the formulation' [7].

Present product 'families' and beyond At present the following NBCD product groups or 'families' have been identified and discussed in the literature: liposomes, polymeric micelles, glatiramoids, iron-carbohydrate complexes, albuminanticancer drug nanoparticles and nanocrystals. The rapidly growing group of nanomedicines will add many NBCDs to this list [9-10]. Interestingly, there are also medicinal products such as the low molecular weight heparins (LMWHs) showing similar complexity but falling under different regulatory policies, i.e. by EMA LMWHs are seen as biologicals and by FDA as non-biologicals.

Over the last few years a number of studies on these NBCD product families have been published. This list is growing and expanding beyond only parenteral drugs. Recently, the present science base,

Author for correspondence: Jon SB de Vlieger, PhD; Dutch Top Institute Pharma, PO Box 142, NL-2300 AC Leiden, The Netherlands

Submitted: 16 September 2015; Revised: 15 October 2015; Accepted: 19 October 2015; Published online first: 2 November 2015 
including the: (1) chemistry and structure; (2) manufacturing; (3) (physico)chemical characterization; (4) pharmacology; and (5) regulatory status, of these product groups was reviewed in a book [9]. The availability of these data in the public domain should contribute to sciencebased discussions and could serve as a model to be followed for consideration of other NBCD product families. In addition, questions regarding interchangeability and substitutability of NBCD follow-on versions have important implications for the handling of such medicinal products by healthcare professionals. Requests are being made by these healthcare professionals for education on the topic of NBCDs and for further, tailor-made, reliable information for patients.

Other candidate NBCD product families that are waiting to be identified include emulsions (parenteral or ocular), dry powder inhalers and oral bioactive polymers such as complex phosphate binders.

\section{The regulatory landscape}

In earlier publications in GaBI Online the differences between the characteristics of small, low molecular weight molecules and biologicals were listed, see Table 1 [11]. If the items in the 'biological drugs' column (in italics) that relate to the biological source of the product and immunogenicity are removed, what remains demonstrates that there is a striking resemblance between the characteristics of biologicals and NBCD products.
Because of this similarity in product characteristics, the NBCD Working Group has proposed on several occasions that regulators should follow the same regulatory pathway for NBCD follow-on products as for biosimilars. This proposal is schematically shown in Figure 1 where 'Totality of evidence' is the key phrase when assessing therapeutic equivalence of NBCD innovator and follow-on products.

Neither FDA nor EMA uses special NBCD regulatory schemes. These agencies use existing pathways for the introduction of innovative and follow-on NBCD products. FDA uses the 505(b)(1)/505(b)(2) and 505(j) pathways for innovator products and follow-on versions, respectively. However, both FDA and EMA are paying increasing attention to regulatory issues related to NBCD families [12-13].

Generally speaking, there are two clearly distinct regulatory documents for these NBCD product families. On the one hand, FDA and/or EMA published 'draft guidance' and/or 'reflection papers' on new products such as liposomes [14], polymeric micelles [15], and surface coatings [16]. On the other hand, both agencies issued documents on the development of follow-on versions of NBCD products such as EMA documents on iron-based nano-colloidal products [17-19] and on existing products [20], and FDA on iron complexes [21], ciclosporin emulsions [22] and on liposome follow-on products [23-24]. Interestingly, FDA has awarded funding to characterize and clinically compare originator and follow-on versions after approving these products [25-26]. It is clear that the present arsenal of regulatory documents from these agencies will be expanded in the years to come. Hopefully, it is not too late to reach global agreement through the World Health Organization (WHO) or perhaps the International Conference on Harmonisation of Technical Requirements for Registration of Pharmaceuticals for Human Use (ICH) initiatives. On the pharmacopoeial side, interest is growing in dealing with NBCD families. For example, a European Directorate for the Quality of Medicines and HealthCare (EDQM) working group is developing a monograph on 'iron sucrose concentrated solution' as an example for non-biological complexes and the United States Pharmacopeia (USP) is currently evaluating similar actions [27]. The British Pharmacopoeia (BP) has published a new monograph on iron sucrose injections, which is basically in line with the USP existing monograph.

One interesting feature of the European legal landscape is that certain NBCD product families are not approved through the centralized procedure (EMA). Instead, approval follows either the purely national procedures or the mutual recognition procedure under the aegis of national competent authorities. This is true for iron sucrose products and for oral bioactive polymer phosphate binders [28]. Considering the complexity of these products and the problems encountered in certain countries with generic versions of NBCD products (see below), approval through the centralized procedure and the CHMP team would be preferred.

\begin{tabular}{|c|c|c|}
\hline & Small molecule drugs & Biological drugs \\
\hline Size & $\begin{array}{l}\text { - Small (single molecule) } \\
\text { - Low molecular weight }\end{array}$ & $\begin{array}{l}\text { - Large (mixture of related molecules) } \\
\text { - High molecular weight }\end{array}$ \\
\hline Structure & $\begin{array}{l}\text { Simple, well-defined, independent } \\
\text { of manufacturing process }\end{array}$ & $\begin{array}{l}\text { Complex (heterogeneous), defined by the } \\
\text { exact manufacturing process }\end{array}$ \\
\hline Modification & Well-defined & Many options \\
\hline Manufacturing & $\begin{array}{l}\text { - Produced by chemical synthesis } \\
\text { - Predictable chemical process } \\
\text { - Identical copy can be made }\end{array}$ & $\begin{array}{l}\text { - Produced in living cell culture } \\
\text { - Difficult to control from starting material } \\
\text { to final API/MP } \\
\text { - Impossible to ensure identical copy version }\end{array}$ \\
\hline Characterization & Easy to characterize completely & $\begin{array}{l}\text { Cannot be characterized completely regard- } \\
\text { ing their molecular composition and their } \\
\text { heterogeneity }\end{array}$ \\
\hline Stability & Stable & Unstable, sensitive to external conditions \\
\hline Immunogenicity & Mostly non-immunogenic & Immunogenic \\
\hline
\end{tabular}

\section{Performance of NBCD products and follow-on versions: evidence in the public domain}

For all NBCD product families where follow-on versions are on the market, a growing number of studies have become available in the public domain demonstrating examples of follow-on products that were approved by (national) competent authorities that differed practice from the originator structurally and/or in clinical 
Figure 1: Similarity approach for complex drugs

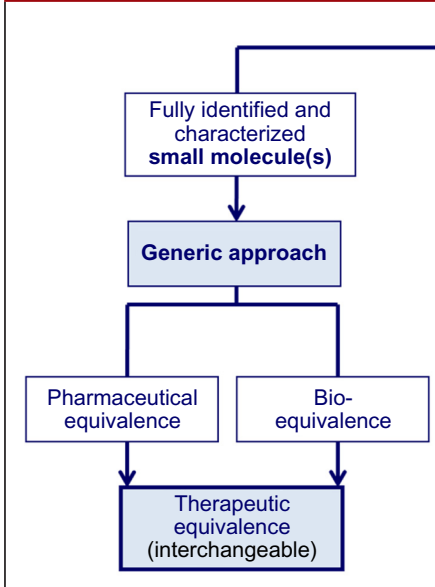

Copy characteristics
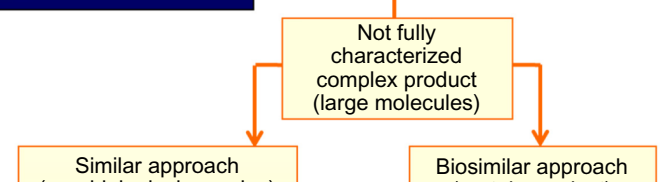
(non-biological complex)

(protein p
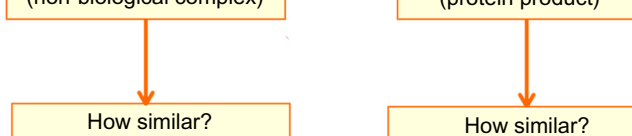

How similar? Totality of the evidence Therapeutic alternative? Substitutable? Interchangeable? Totality of the evidence Therapeutic alternative? Substitutable? Interchangeable?

Schellekens H et al. The therapeutic equivalence of complex drugs. Regul Toxicol Pharmacol. 2011;59(1):176-83.

products [9]. Often these differences were clinically relevant. Examples include publications by Rottembourg et al. [29]; Martin-Malo et al. [30]; Stein et al. [31]; Lee et al. [32] and Agüera et al. [33] for iron sucrose similars; and Weinstein et al. [34] and Towfic et al. [35] for glatiramer acetate follow-on products. These (clinical) examples raise questions to the regulatory science community in the countries mentioned in these publications about how appropriate the current systems are in ensuring equivalence in NBCD product quality, efficacy and safety. Is the current approach rigorous enough?

These examples provide lessons that should be communicated throughout the scientific community as well as to medical/ pharmaceutical practitioners. Moreover, in the years to come, study of these examples can also help competent authorities to establish appropriate, science-based approval procedures for these complex drug products.

\section{The future: Quo Vadis?}

Expanding: The number of NBCD product families will continue to grow. It is time to pay attention to these (new) families and discuss their specific characteristics and their implications for the regulatory process at an early stage. Much information is often already available but there is a need to go through the archives and analyse these data so that scientific deficiencies are brought to the forefront.

Outstanding issues: for a list of outstanding issues concerning NBCD products one can refer to the list drawn up for biologicals.
For example, labelling, comparability and attribute drift, NBCD-questionables (cf. bio-questionables [36]), extrapolation [37], interchangeability, substitution, and last but not least: a single global approach (WHO in the lead?) [38].

Facts please: For a fact-based debate on NBCD products we need to stimulate publications in the public domain. This will strengthen the science base for decisionmaking. Transparency of the regulatory process is another essential element for such a discussion. We hope that all parties (academic, industry and regulatory) involved in this debate will continue, and even step up their efforts to provide this science base.

Goal: We feel that the GaBI Journal and the GaBI Online platform offer excellent opportunities to stimulate awareness around the critical issues related to both new, innovative NBCD products and the introduction of follow-on versions. The growing science base for NBCD product legislation, e.g. in Europe and the US, and hopefully in other countries in the future, needs a non-biased publication outlet. With the GaBI publication platform we have the ambition to become the central and preferred publication hotspot for this complex topic.

\section{Authors}

Jon SB de Vlieger, PhD

Dutch Top Institute Pharma, PO Box 142, NL-2300 AC Leiden, The Netherlands

Professor Stefan Mühlebach, $\mathrm{PhD}$

Vifor Pharma Ltd, 61 Flughofstrasse, PO Box, CH-8152 Glattbrugg, Switzerland; Department of Pharmaceutical Sciences,
Pharmacenter, University of Basel, 50 Klingelbergstrasse, CH-4056 Basel, Switzerland

Vinod P Shah, PhD

NBCD Steering Committee member, Pharmaceutical Consultant, 11309 Dunleith Place, North Potomac, MD 20878, USA

Scott E McNeil, PhD

Director, Nanotechnology Characterization Laboratory, Frederick National Laboratory for Cancer Research, Leidos Biomedical Research Inc, PO Box B, Frederick, MD 21702-1201, USA

Professor Gerrit Borchard, PharmD, PhD Professor, Biopharmaceutical Sciences, School of Pharmaceutical Sciences, University of Geneva, University of Lausanne 30, Quai Ernest-Ansermet, CH-1211 Geneva 4, Switzerland

Vera Weinstein, PhD

Teva Pharmaceutical Industries Ltd, Discovery and Product Development, Global Research and Development, Netanya, Israel

Beat Flühmann, PhD

Vifor Fresenius Medical Care Renal Pharma Ltd, 37 Rechenstrasse, PO Box, CH-9001 St Gallen, Switzerland

Sesha Neervannan, $\mathrm{PhD}$

Senior Vice President, Pharmaceutical Development Brands R \& D, Allergan Plc, RD2-3A, 2525 Dupont Drive, Irvine, CA 92612, USA

Emeritus Professor Daan JA Crommelin, $\mathrm{PhD}$

Department of Pharmaceutical Sciences, Utrecht Institute for Pharmaceutical Sciences, Utrecht University, The Netherlands

Competing interest: All authors are members of the steering committee of the NonBiological Complex Drug (NBCD) Working Group, hosted at the Dutch Top Institute Pharma (TI Pharma), Leiden, The Netherlands (http://www.tipharma.com/NBCD).

Provenance and peer review: Not commissioned; externally peer reviewed.

\section{References}

1. Mühlebach S, et al. The authorization of nonbiological complex drugs (NBCDs) follow-on versions: specific regulatory and interchangeability rules ahead? Generics and Biosimilars Initiative Journal (GaBI) Journal. 2013;2(4):204-7. doi:10.5639/gabij.2013.0204.054 
2. Borchard G. Complex molecules - current developments. Generics and Biosimilars Initiative Journal (GaBI Journal). 2014;3(2):54-5. doi:10.5639/gabij. 2014.0302.016

3. Walson PD, Mühlebach S, Flühmann B. First AsiaPacific educational workshop on non-biological complex drugs (NBCDs), Kuala Lumpur, Malaysia, 8 October 2013. Generics and Biosimilars Initiative Journal (GaBI Journal). 2014;3(1):30-3. doi:10.5639/gabij.2014.0301.010

4. Nicholas MJ. Clinical development, immunogenicity, and interchangeability of follow-on complex drugs. Generics and Biosimilars Initiative Journal (GaBI Journal). 2014;3(2):71-8. doi:10.5639/ gabij.2014.0302.020

5. Schellekens H, Klinger E, Mühlenbach S, Brin JF, Storm G, Crommelin DJ. The therapeutic equivalence of complex drugs. Regul Toxicol Pharmacol. 2011;59(1):176-83.

6. TI Pharma. Non Biological Complex Drugs Working Group [homepage on the Internet]. 2015 [cited 2015 Oct 15]. Available from: http://www. tipharma.com/nbcd

7. Crommelin DJ, de Vlieger JS, Weinstein V, Mühlebach S, Shah VP, Schellekens H. Different pharmaceutical products need similar terminology. AAPS J. 2014;16(1):11-4.

8. Schellekens $\mathrm{H}$, et al. How to regulate non-biological complex drugs (NBCD) and their follow-on versions: points to consider. AAPS J. 2014;16(1):15-21.

9. Crommelin DJA, de Vlieger, JSB. Non-biological complex drugs. The science and the regulatory landscape. Advances in the Pharmaceutical Sciences series. NY: AAPS/Springer; 2015.

10. Mühlebach S, Borchard G, Yildiz S. Regulatory challenges and approaches to characterize nanomedicines and their follow-on similars. Nanomedicine (Lond) 2015; 10(4):659-74.

11. GaBI Online - Generics and Biosimilars Initiative. Small molecule versus biological drugs [www. gabionline.net]. Mol, Belgium: Pro Pharma Communications International; [cited 2015 Oct 15]. Available from: www.gabionline.net/Biosimilars/ Research/Small-molecule-versus-biological-drugs

12. Ehmann F, et al. Next-generation nanomedicines and nanosimilars: EU regulators' initiatives relating to the development and evaluation of nanomedicines. Nanomedicine (Lond). 2013;8(5): 849-56.

13. Spicher K, et al. Differences in tissue distribution of iron from various clinically used intravenous iron complexes in fetal avian heart and liver. Regul Toxicol Pharmacol. 2015;73(1):65-72.

14. U.S. Food and Drug Administration. Center for Drug Evaluation and Research (CDER). Guidance for industry. Liposome drug products chemistry, manufacturing, and controls; human pharmacokinetics and bioavailability; and labeling documentation. Draft guidance. 2002 [homepage on the Internet]. 2002 Jul 29 [cited 2015 Oct 15]. Available from: http://www.fda.gov/downloads/ drugs/guidancecomplianceregulatoryinformation/ guidances/ucm070570.pdf

15. European Medicines Agency. Committee for Medicinal Products for Human Use (CHMP). Joint MHLW/EMA reflection paper on the development of block copolymer micelle medicinal products. 17 January 2013 [homepage on the Internet]. 2013 Jan 23 [cited 2015 Oct 15]. Available from: http://www.ema.europa.eu/docs/en_GB/ document_library/Scientific_guideline/2013/02/ WC500138390.pdf

16. European Medicines Agency. Committee for Medicinal Products for Human Use (CHMP). Reflection paper on surface coatings: general issues for consideration regarding parenteral administration of coated nanomedicine products. 22 May 2013 [homepage on the Internet]. 2013 Jul 19 [cited 2015 Oct 15]. Available from: http://www. ema.europa.eu/docs/en_GB/document_library/ Scientific_guideline/2013/08/WC500147874.pdf

17. European Medicines Agency. Committee for Human Medicinal Products (CHMP). Reflection paper on non-clinical studies for generic nanoparticle iron medicinal product applications. $17 \mathrm{March}$ 2011 [homepage on the Internet]. 2011 Apr 1 [cited 2015 Oct 15]. Available from: http://www. ema.europa.eu/docs/en_GB/document_library/ Scientific_guideline/2011/04/WC500105048.pdf

18. European Medicines Agency. Committee for Medicinal Products for Human Use (CHMP). Overview of comments received on reflection paper on the data requirements for intravenous iron-based nano-colloidal products developed with reference to an innovator medicinal product. 26 March 2015 [homepage on the Internet]. 2015 Mar 26 [cited 2015 Oct 15]. Available from: http://www.ema.europa. eu/docs/en_GB/document_library/Overview_of_ comments/2015/03/WC500184921.pdf

19. European Medicines Agency. Committee for Medicinal Products for Human Use (CHMP). Reflection paper on the data requirements for intravenous iron-based nano-colloidal products developed with reference to an innovator medicinal product. 26 March 2015 [homepage on the Internet]. 2015 Mar 26 [cited 2015 Oct 15]. Available from: http://www.ema.europa.eu/docs/en GB/document_library/Scientific_guideline/ 2015/03/WC500184922.pdf

20. European Medicines Agency. Assessment report for: iron containing intravenous (IV) medicinal products. 13 September 2013 [homepage on the Internet]. 2013 Sep 27 [cited 2015 Oct 15]. Available from: www.ema.europa.eu/docs/ en_GB/document_library/Referrals_document/ IV_iron_31/WC500150771.pdf

21. U.S. Food and Drug Administration. Draft guidance on iron sucrose [homepage on the Internet]. 2013 Nov 1 [cited 2015 Oct 15]. Available from: http://www.fda.gov/downloads/drugs/guidancecomplianceregulatoryinformation/guidances/ ucm297630.pdf
22. U.S. Food and Drug Administration. Draft guidance of cyclosporine [homepage on the Internet]. 2013 Jun 20 [cited 2015 Oct 15]. Available from http:// www.fda.gov/downloads/drugs/guidancecomplianceregulatoryinformation/guidances/ucm358114.pdf

23. U.S. Food and Drug Administration. Draft guidance on doxorubicin hydrochloride [homepage on the Internet]. 2014 Dec 12 [cited 2015 Oct 15]. Available from http://www.fda.gov/downloads/ Drugs/.../Guidances/UCM199635.pdf

24. European Medicines Agency. Committee for Human Medicinal Products (CHMP). Reflection paper on the data requirements for intravenous liposomal products developed with reference to an innovator liposomal products. 21 February 2013 [homepage on the Internet]. 2013 Mar 13 [cited 2015 Oct 15]. Available from: http://www. ema.europa.eu/docs/en_GB/document_library/ Scientific_guideline/2013/03/WC500140351.pdf

25. Federal Business Opportunities. Therapeutic equivalence of generic iron complex product [homepage on the Internet]. [cited 2015 Oct 15]. Available from: https://www.fbo.gov/index?s=opportunity\&mode= form\&id=592788989854da145c8e7b6d103c898d\&tab= core $\&$ tabmode $=$ list $\&$

26. National Institutes of Health. Michel SL, Kane MA, Polli JE. Evaluation of iron species in healthy subjects treated with generic and reference sodium ferric gluconate [homepage on the Internet]. [cited 2015 Oct 15]. Available from: http://grantome.com/grant/NIH/U01-FD005266-01

27. U.S. Pharmacopeial Convention. Monographs in need of modernization (Last updated 26 November 2014) [database on the Internet]. [cited 2015 Oct 15]. Available from: http://www.usp.org/ sites/default/files/usp_pdf/EN/USPNF/2014-1126_monographs_needing_modernization.xlsx

28. CBG-MEB. [Openbaar verslag 797e Collegevergadering verslag]. Dutch [homepage on the Internet]. [cited 2015 Oct 15]. Available from: http://www.cbgmeb.nl/documenten/vergaderstukken/2014/01/09/ collegevergadering-797-verslag

29. Rottembourg J, Kadri A, Leonard E, Dansaert A, Lafuma A. Do two intravenous iron sucrose preparations have the same efficacy? Nephrol Dial Transplant. 2011;26(10):3262-7.

30. Martin-Malo A, Merino A, Carracedo J, et al. Effects of intravenous iron on mononuclear cells during the haemodialysis session. Nephrol Dial Transplant. 2012;27(6):2465-71.

31. Stein J, Dignass A, Chow KU. Clinical case reports raise doubts about the therapeutic equivalence of an iron sucrose similar preparation compared with iron sucrose originator. Curr Med Res Opin. 2012;28(2):241-3.

32. Lee ES, Park BR, Kim JS, Choi GY, Lee JJ, Lee IS. Comparison of adverse event profile of intravenous iron sucrose and iron sucrose similar in postpartum and gynecologic operative patients. Curr Med Res Opin. 2013;29(2):141-7.

To continue on page 172 